\title{
SLEEP PATTERNS AND SYMPTOMS OF ANXIETY AND DEPRESSION IN PATIENTS WITH CHRONIC PAIN
}

\author{
Martha M.C. Castro ${ }^{1,2}$, Carla Daltro
}

\begin{abstract}
Background: Sleep disturbances and symptoms of anxiety and depression have been shown to be involved in the genesis and perpetuation of chronic pain. Objective: To evaluate sleep patterns and the prevalence of symptoms of anxiety and depression in patients with chronic pain. Method: Four hundred consecutive patients referred to a chronic pain outpatient clinic were investigated using patient charts, the numerical Visual Analogue Scale for the evaluation of pain, the Hospital Anxiety and Depression scale and the Mini-Sleep Questionnaire. Results: The mean age of patients was $45.6 \pm 11.4$ years. The most frequent medical diagnosis was myofascial pain followed by neuropathic pain. The prevalence of symptoms of anxiety was $72.8 \%$, depression $93 \%$ and altered sleep patterns $93 \%$. Conclusion: This study revealed a high prevalence of symptoms of depression and anxiety and alterations in sleep patterns in patients with chronic pain, justifying investigation into these disturbances in this group of patients.
\end{abstract}

KEY WORDS: chronic pain, sleep, depression, anxiety.

\begin{abstract}
Padrão do sono e sintomas de ansiedade e depressão em pacientes com dor crônica
Resumo - Contexto: Distúrbios do sono e sintomas de ansiedade e depressão tem sido vistos no envolvimento da origem e perpetuação da dor crônica. Objetivo: Avaliação do padrão do sono e da prevalência de sintomas de ansiedade e depressão em pacientes com dor crônica. Método: Quatrocentos pacientes de dor crônica atendidos consecutivamente na clínica foram investigados usando os seguintes instrumentos a Escala Visual Analógica para a avalição da dor, a Escala Hospitalar de Ansiedade e Depressão e o Mini-Sleep Questionnaire. Resultados: A média de idade dos pacientes foi 45,6 $6 \pm 11,4$ anos. $O$ diagnóstico mais frequente foi de dor miofascial seguido de dor neuropática. A prevalência de sintomas de ansiedade foi $72,8 \%$, de depressão foi $61,5 \%$ e de alteração do sono $93 \%$. Conclusão: Este estudo revela uma alta prevalência de sintomas de depressão e ansiedade e alterações no padrão do sono em pacientes com dor crônica, justificando a investigação destes distúrbios neste grupo de pacientes.
\end{abstract}

PALAVRAS-CHAVE: dor crônica, sono, depressão, ansiedade.

The International Association for the Study of Pain (IASP) defines pain as "an unpleasant sensory and emotional experience associated with actual or potential tissue damage, or described in terms of such damage. Each individual learns the application of the word through experiences related to injury in early life ...". . Based on this definition, it was found that there is no single direct relationship between pain and tissue damage, since pain involves sensitive, cognitive, emotional and cultural elements ${ }^{2}$.

Chronic pain is defined in the literature as pain that persists after the injury has healed; pain that is continuous and recurrent. In general, it is characterized as nonspecific, poorly defined and aggravated by environmental or psychopathological stress factors, provoking functional incapacity and transforming the affective, social, financial, productive and sexual life of the individual by weakening his/her relationship with the surrounding world ${ }^{3}$. What the literature has shown is that, even in eminently organic cases, psychological factors have significant effects on complaints of pain. Studies show that there is a significant association between chronic pain and anxiety, depression and changes in sleep quality, these symptoms preceding and predisposing individuals to develop complaints of chronic pain in the same way that chronic painful pathologies stimulate the appearance of these symptoms ${ }^{4-6}$.

The objective of this study was to evaluate the sleep

${ }^{1}$ Pain Clinic, Professor Edgard Santos University Hospital, Federal University of Bahia, Salvador BA, Brazil; ${ }^{2}$ Bahia School of Medicine and Public Health, Salvador BA, Brazil.

Received 23 June 2008, received in final form 30 October 2008. Accepted 6 December 2008.

Dra. Martha Moreira Cavalcante Castro - Avenida Professor Magalhães Neto 1541 - Hospital da Bahia / Sala 3014 - $41810-011$ Salvador BA - Brasil. E-mail:marthamcastro@uol.com.br 
patterns and the frequency of symptoms of anxiety and depression in patients with chronic pain receiving care at the pain clinic of the Professor Edgard Santos University Teaching Hospital in Salvador, Bahia, Brazil.

\section{METHOD}

A cross-sectional descriptive study was carried out in the pain clinic located in the Magalhães Neto Outpatient Department at the Professor Edgard Santos University Teaching Hospital. This pain outpatient clinic was established in 1996 following implementation of the Multidisciplinary Program of Teaching, Assistance, Research and Extension, one of its objectives being to provide specialized multidisciplinary care to chronic pain patients. Following patient consent, data were collected between March 2003 and July 2006 using the following instruments: a questionnaire containing items designed to obtain patients' demographic data: age, gender, marital status, education level, religion, profession, current occupation (whether currently employed, on sick leave or retired), and questions regarding the pain (medical diagnosis, duration, frequency, time of treatment at this clinic and response to the treatment implemented); Visual Analogue Scale (VAS) for the evaluation of pain in which scores consisted of: 0-1, no pain; $2-3$, mild pain; 4-5, moderate pain; 6-7, intense or severe pain; and 8-10, unbearable pain ${ }^{7}$; Hospital Anxiety and Depression (HAD) scale, designed by Zigmond and Snaith in 1983 and validated by Botega et al. in $1998^{8}$, which contains 14 items, 7 concerning anxiety and 7 on depression, with a cut-off point of 8 for anxiety and 9 for depression; and the Mini-Sleep Questionnaire (MSQ). Inclusion criteria consisted of patients who had had chronic pain for at least three months, a duration that defines the chronic nature of the pain. Exclusion criteria consisted of those patients with chronic pain of oncological origin. Independent variables were: age, gender, marital status, place of birth, religion, education level, principal occupation, profession, medical diagnosis of pain, duration of pain (in years), frequency of pain, time of treatment at this clinic, and the patient's response to the medical treatment implemented at the clinic. Dependent variables consisted of: intensity of pain (VAS) and anxiety, depression and sleep scores. All patients signed an informed consent form prior to initiation of the study.

The protocol was approved by the Internal Review Board of the Federal University of Bahia.

\section{Statistical analysis}

The Statistical Package for the Social Sciences (SPSS) software program was used to construct the databases and perform the statistical calculations. The results of the continuous variables were presented in the form of means \pm standard deviations or median and interquartile range according to their distribution. The categorical variables were expressed as relative frequencies. The chi-square test was used to test the association between the categorical variables. All the tests were two-tailed and were applied following verification of the prerequisites for their use. Pvalues $<0.05$ were considered statistically significant.

\section{RESULTS}

Four hundred patients with a mean age of $45.6 \pm 11.4$ years were evaluated. Of these 400 patients, 331 (82.8\%) were female. Table 1 shows the sociodemographic characteristics of the study population.

Investigation of pain showed that the most frequent diagnoses were myofascial and neuropathic pain. One hundred patients $(25 \%)$ reported having experienced the pain for periods $\leq 2$ years, 129 (32.3\%) for $2-5$ years and 99 (24.8\%) from 5 to 10 years, while 72 patients (18\%) reported a duration of pain of ten years or more. Most of the patients ( $n=283 ; 70.8 \%$ ) reported experiencing pain daily, while 77 patients (19.3\%) reported feeling pain fewer than three times a week and 40 patients (10\%) reported experiencing pain once a week. A total of 194 patients (48.5\%)

Table 1. Sociodemographic data of the 400 patients receiving care at the pain clinic in a university teaching hospital between 2003 and 2006.

\begin{tabular}{llcc}
\hline Variables & & $\mathrm{n}$ & $\%$ \\
\hline Gender & Female & 331 & 82.8 \\
& Male & 69 & 17.3 \\
Religion & Catholic & 220 & 55.0 \\
& Other religions & 151 & 37.8 \\
& No religion & 27 & 6.8 \\
Education level & University & 32 & 8.0 \\
& High school & 279 & 69.8 \\
Professional activities & Illiterate/primary school & 89 & 22.3 \\
& Currently working & 129 & 32.3 \\
& On sick leave due to the pain & 154 & 38.5 \\
& Unemployed / Retired & 117 & 29.3 \\
\hline
\end{tabular}


Table 2. Prevalence of anxiety, depression and sleep abnormalities in 400 patients receiving care at the pain clinic in a university teaching hospital between 2003 and 2006.

\begin{tabular}{lcc}
\hline Variables & $\mathrm{n}$ & $\%$ \\
\hline Anxious & 291 & $72.8 \%$ \\
Not anxious & 109 & $27.3 \%$ \\
Depressed & 246 & $61.5 \%$ \\
Not depressed & 154 & $38.5 \%$ \\
Normal sleeping pattern & 28 & $7 \%$ \\
Abnormal sleeping pattern & 371 & $93 \%$ \\
\hline
\end{tabular}

reported having been in treatment for three months or less, $112(28 \%)$ for 3-6 months, $45(11.3 \%)$ for 6 months to one year, and 38 (9.5\%) for $1-3$ years, while only 11 patients (2.8\%) reported having been in treatment at the clinic for more than three years.

With respect to the level of treatment response obtained since enrolling at the clinic, 154 patients $(38.6 \%)$ reported having achieved slight relief from the pain, while 152 (38.1\%) reported moderate relief, 65 (16.3\%) reported having obtained no relief at all and 28 patients $(7 \%)$ reported having achieved total relief from the pain.

Table 2 shows the prevalence of symptoms of anxiety and depression, and the sleep patterns of the patients in this study.

\section{DISCUSSION}

The findings of this study showed a high prevalence of symptoms of anxiety and depression and altered sleep patterns.

The prevalence of females in this sample is compatible with other reports published in the literature, and may be related to the presence of constitutional, endocrinal, cultural and behavioral aspects in women ${ }^{10}$. With respect to the mean age of 45.6 years, this finding is in agreement with other reports in the literature, as is the finding that the majority of patients were not currently carrying out their professional activities, a fact that corroborates the limiting nature of the pain". The social damage resulting from the pain is an indicator of the impact of the symptom on the life of the affected individual, suggesting a change in the patient's quality of life with respect to being able to carry out physical, intellectual, psychic and occupational activities $^{12}$.

Similar numbers of patients reported moderate or slight pain relief and this reflects the fact that in this sample population most of the patients had been undergoing treatment at this clinic for less than three months. This time of treatment is insufficient to obtain an adequate response in cases of chronic pain. On the other hand, the high rate of improvement may be indicative of the clinic's efficacy, reflecting the effectiveness of the multidisciplinary team. Those in whom no improvement occurred may belong to a group in which a longer period of time may be necessary to achieve therapeutic results.

Analysis of the responses obtained with the use of the HAD scale suggests that the high percentage of anxious and depressed patients may be due to the concomitance of these symptoms in patients with chronic pain ${ }^{13}$.

The prevalence of altered sleep patterns in this sample population is in agreement with data in the literature showing the interrelationship between chronic pain and abnormal sleep patterns. The presence of a cycle in which sleep abnormalities aggravate symptoms of pain and affective symptoms is already known, as are the mechanisms by which these symptoms alter sleep patterns. This is the result of numerous contributing factors including reduced physical activity during the day and the use of various painkillers that interfere with sleep patterns. Therefore, it is reasonable to speculate that the pain experienced by patients may be accentuated by the interruption or absence of sleep ${ }^{14}$.

The use of evaluation scales serves to detect symptoms and is not, therefore, used for diagnosis. Instruments such as the Hospital Anxiety and Depression (HAD) scale may suggest the presence of mood disturbances that may otherwise have gone unnoticed, since they do not take into account common confounding symptoms in clinical disease and depression such as fatigue, loss of appetite and sleep disturbances, among others. This instrument has the advantage of screening subjective symptoms that are more specific for depression; hence the final result reflects whether adequate diagnostic instruments are necessary or not to identify and implement treatment in these patients. Moreover, cultural and social factors may contribute to the understanding and meaning given to the terms used in the HAD scale ${ }^{15,16}$.

In conclusion, this cross-sectional study was the first to be carried out in this population with the objective of classifying comorbid sleep pattern changes and symptoms of anxiety and depression in patients receiving care at the pain clinic in this university teaching hospital. There was a high prevalence of symptoms of anxiety and depression and of sleep pattern abnormalities, highlighting the need for further investigation.

\section{REFERENCES}

1. Oliveira AS, Bermudez CC, Souza RA, et al. Pain impact on life of patients with temporomandibular disorder. J Appl Oral Sci 2003;11:138-143.

2. Bruch A, Rosa JL, Leopoldo ACR, et al. Relation of mental disturbs in population with musculoskeletal or rheumatologic disorders. Rev Dor 2006;7:875-881. 
3. Souza FAEF, Silva JA. Avaliação e mensuração de dor em contextos clínicos e de pesquisa. Rev Dor 2004;5:408-429.

4. Pincus T, Vlaeyen JW, Kendall NA, et al. Cognitive-behavioral therapy and psychosocial factors in law back pain: directions for the future. Spine 2002;27:E133-E138.

5. Thommasen HV, Zhang W. Impact of chronic disease on quality of life in the Bella Coola Valey. Rural Remote Health 2006;6:528.

6. Kurita GP, Pimenta CAM. Adesão ao tratamento da dor crônica: estudos das variáveis demográficas terapêuticas e psicossociais. Arq Neuropsiquiatr 2003;61:416-425.

7. Ciaramella A, Grosso S, Poli P, et al. When pain is not fully explained by organic lesion: a psychiatric perspective on chronic pain patients. Eur J Pain 2004;8:13-22.

8. Botega NJ, Pondé MP, Medeiros P, Lima MG, Guerreiro CAM. Validação da escala hospitalar de ansiedade e depressão (HAD) em pacientes epilépticos ambulatoriais. J Bras Psiquiatr 1998;47:285-289.

9. Gorestein C, Tavares S, Alóe F. Questionários de auto-avaliação de sono. In: Gorestein C, Andrade LHS, Zuard AW (eds). Escalas de avaliação clínica em psiquiatria e psicofarmacologia. São Paulo: Lemos, 2000:423-434.
10. Turner JA, Mancl L, Aaron LA. Short- and long-term efficacy of brief cognitive-behavioral therapy for patients with chronic temporomandibular disorder pain: a randomized, controlled trial. Pain 2006;121: 181-194.

11. Goossens ME, Vlaeyen JW, Hidding A, Kole-Snijders A, Evers SM. Treatment expectancy affects the outcome of cognitive-behavioral interventions in chronic pain. Clin J Pain 2005;21:18-26.

12. Pagano T, Matsutani LA, Ferreira EAG, Marques AP, Pereira CAB. Avaliação da ansiedade e qualidade de vida em pacientes com fibromialgia. São Paulo Med J 2004;122:252-258.

13. Matta APC, Moreira PF Filho. Sintomas depressivos e ansiedade em pacientes com cefaléia do tipo tensional crônica episódica. Arq Neuropsiquiatr 2003;61:991-994.

14. Teixeira MJ, Lin TY. Dor e sono. In: Reimão R (Ed). Temas de medicina do sono. São Paulo: Lemos, 2000:149-163.

15. Haythornthwaite JA, Sieber WJ, Kerns RD. Depression and the chronic pain experience. Pain 1991;46:177-184.

16. Pimenta CAM. Dor crônica, terapia cognitivo-comportamental e o enfermeiro. Rev Psiquiatr Clin 2001;28:288-294 